\title{
RESISTANCE TESTS ON FIRE BRICKS UNDER LOADS AT HIGH TEMPERATURES ${ }^{1}$
}

By F. Sizurin and Fradr. Carlsson'2

Experiments carried out by B. KJELLGREN

\section{ABSTRACT}

Method.-Mixtures of fine ground china clay and ball clay with grog (called by the author "chamotte") of the same materials were made into $3 \mathrm{~cm}$. cubes and subjected to a pressure of $2 \mathrm{~kg}$. per sq. $\mathrm{cm}$. at temperatures which sufficed to bring about a linear contraction of 0.3 per cent in 2 hours. Definite quantities of silica, alumina, ferric oxide, lime and magnesia were added and both the deformation and the usual softening points determined.

Results.-Even very small amounts of the oxides of iron, calcium and magnesium brought about a considerable reduction in the resistance to pressure. A minimum in the resistance was observed with silica contents between $60-70$ per cent, which does not correspond to the minimum softening point or melting point of clay-silica mixtures. Additions of alumina increased the temperature required to deform the specimens but with high alumina content mechanical failure due to lack of bonding material occurred. For many purposes clay fire brick will have to be replaced by more resistant materials, such as brick made from silica, aluminous mixtures and silicon carbide.

Formerly, when judging the properties of fire bricks, great importance was attached to the melting point (shown by Seger cones) and to the chemical composition, as regards ordinary fire bricks to the alumina contents particularly. Experience, however, has shown that such determinations do not fully indicate the properties of these refractory products. It has become more and more evident that the importance of determining the melting points by Seger cones has been over-estimated. - This is especially the case with fire clay material owing to the fact that this material shows a considerable softening interval between $300^{\circ}$ and $400^{\circ} \mathrm{C}$.

Investigators, therefore, soon endeavored to find other methods which would better illustrate the real properties of the materials

1 Received December 31, 1921.

${ }^{2}$ Communicated by the Laboratory of the Höganäs Works at Höganäs, Sweden. 
and they discovered a particularly good method for this purpose in the determination of the resistance under load at high temperatures. ${ }^{1}$

In carrying out such investigations it will frequently be noticed that even slight variations in the chemical composition cause important changes in the resistance under load at high temperatures. It may therefore be of interest to examine the influence of variations in the chemical composition. The following investigations have been carried out with this object.

As is known a fire brick is made of a mixture of raw clay and grog. Obviously when investigating the influence of a substance upon the properties of a material, this substance must be extremely intimately mixed with the binding clay as well as with the grog. These investigations were therefore carried out in such a manner that a normal clay of known composition was minutely wetground during 12 hours in a ball mill along with the substance being examined. By means of screening, it was found that no residue was left after passing through a 10,000 meshes per square centimeter.

One part of this very finely ground mixture was burnt to chamotte at cone $14\left(1410^{\circ} \mathrm{C}\right)$, then crushed and screened partly to grains between screens No. 4 and No. 20 (i.e., 4 and 20 meshes per lineal inch, respectively), partly to a product finer than No. 7 (i.e., 7 meshes per lineal inch). The different kinds of chamotte were then mixed with raw clay in the proportions of one part chamotte to one part raw clay and cubes a little more than $30 \mathrm{~mm}$. square were formed with this mixture. Cubes were made of each mixture partly with chamotte screened through 7 meshes and partly with chamotte in grains between 4 and 20 meshes, $i$. e., with the fine powder sieved away. These cubes were then burnt at cone 14 and afterwards cut as exactly as possible to $30 \mathrm{~mm}$. square.

Certain quantities of $\mathrm{SiO}_{2}, \mathrm{Al}_{2} \mathrm{O}_{3}, \mathrm{Fe}_{2} \mathrm{O}_{3}, \mathrm{CaO}$ and $\mathrm{MgO}$ were added to the raw mixture. With each mixture the fusion point was determined in the usual manner by cone as was also the softening temperature. The latter is defined as "the temperature at which the test cube exposed during two hours to a load of 2 kilos

1 Ċ. K. Endell, "Über das Verhalten feuerfester Steine unter Belastung bei hohen Temperaturen," Stahl u. Eisen, 1921 H. 1. 
per square $\mathrm{cm}$. experiences a lineal contraction of 0.3 per cent of the original length."

The heat took place in an electric resistance furnace, the resistor consisting of granular (14-29 mesh) retort carbon contained between two vertical coaxial tubes of carborundum.

A carborundum rod with its upper surface at the center of the furnace served as the support for the test tube and the Seger cones. Pressure was applied to the test piece by means of a loaded rod of carborundum.

Investigations proceeded simultaneously in 4 furnaces, connected as shown in Fig. 1, so that an exact regulation of the electric

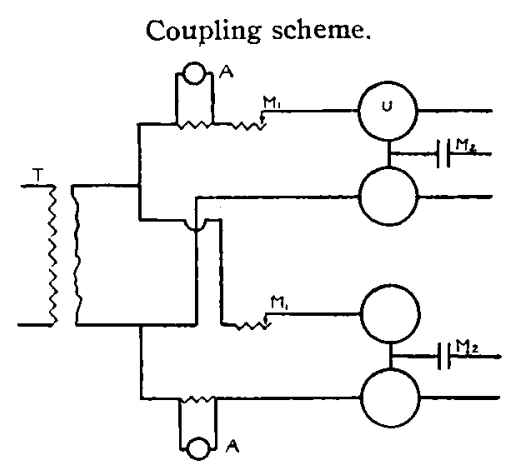

FIG. 1.-T, Transformer; A, Ampèremeter; $M_{1}$, Iron wire resistance; $\mathrm{M}_{2}$, Liquid resistance; U, Furnace. current could be arranged by means of a liquid resistance. The main current from the transformer was regulated by means of a water-cooled iron wire resistance. The furnaces were coupled on a transformer with a secondary tension of 110 volts; consequently each furnace received about 55 volts. The load for each furnace was about $35 \mathrm{kw}$. at $1500^{\circ} \mathrm{C}$ and about $20 \mathrm{kw}$. at $1350^{\circ} \mathrm{C}$.

The tests were carried out in these comparatively large furnaces in order to enable the temperature to be kept as steady as possible. The temperature was determined by means of Seger cones which were placed in the furnaces at certain intervals.

The tubes, as well as the pressing rod of silicon carbide proved to be extremely suitable for the purpose. The tubes were used during months of testing and they were often suddenly cooled without cracking. When the cubes were changed, the pressing rods were frequently taken out while white hot, but in spite of this they did not crack.

The temperature was regulated in the following manner: For the determination of the desired temperature, for instance that of cone 10 , the cones numbers 9,10 and 11 were set down in 
the furnace whereupon cone 9 bent down suddenly, cone 10 bent little by little until the point touched the bed, while cone $11 \mathrm{did}$ not bend. The furnace being so exactly regulated that cone 11 remained unbent, the temperature was considered as having been reached. During the carrying out of the experiments, new cones numbers 9 and 10 were set down every hour, and in this manner the temperature could easily be kept practically constant during each testing period. The furnaces were often running day and night in order to avoid the heating periods. As showing the exactness of the regulation of the temperature it may be stated that during a period of 6 to 8 hours the point of each new cone 10 touched the bed after one hour exactly.

In order to determine the softening temperature for a test mixture, a series of pressure tests was carried out, first at high temperature and then at temperatures lower and lower, until, finally, the test cube was no longer compressed. The softening temperature was considered to have been reached at a contraction of 0.3 per cent. For instance, on pressing the original material, the following results were obtained:

$\begin{array}{rc}\text { Cone } & \text { Per cent contraction at the end of } 2 \text { hours } \\ 11 & 2.9 \\ 11 & 3.2 \\ 10 & 0.9 \\ 10 & 1.2 \\ 9 & 0.3 \\ 9 & 0.2 \\ 8 & 0.0 \\ 8 & 0.0\end{array}$

The softening temperature is consequently to be found between cone 9 and cone 10 , but nearer cone 9 .

The primary mass consisting of 1 part blue clay and 1 part washed china clay, gave the following analysis (after calcination).

$\begin{array}{llllllll}\mathrm{SiO}_{2} & \mathrm{Al}_{2} \mathrm{O}_{3} & \mathrm{Fe}_{2} \mathrm{O}_{3} & \mathrm{CaO} & \mathrm{MgO} & \mathrm{K}_{2} \mathrm{O} & \mathrm{Na}_{2} \mathrm{O} & \text { Total } \\ 54.52 & 43.04 & 0.89 & 0.68 & \text { traces } & 0.78 & 0.0 & 99.91 \\ \text { Fusion point given as cone } 34\left(1750^{\circ} \mathrm{C}\right) . & & & \end{array}$

To this mixture certain quantities of $\mathrm{SiO}_{2}, \mathrm{Al}_{2} \mathrm{O}_{3}, \mathrm{Fe}_{2} \mathrm{O}_{3}, \mathrm{CaO}$, and $\mathrm{MgO}$ were added in the purest possible form. The silicious material was added in the form of the purest quartz, the alumina, 
oxide of iron and magnesia in chemically pure form, and the lime as chemically pure precipitated chalk. The Seger formula was calculated from the original analysis and on the basis of this a certain number of moles of the different oxides were added (see the various tables). The percentages were all calculated.

\section{Increase of the Percentage of Silica}

The silica was added in the form of quartz with $\mathrm{SiO}_{2}$ content about 9.9 per cent.

The different mixtures and the results of the investigation are shown in Table I and Fig. 2. The underlined figures indicate the cones most nearly corresponding to the temperature in question.

\begin{tabular}{|c|c|c|c|c|c|c|}
\hline $\begin{array}{c}\text { Number } \\
\text { of SiO, } \\
\text { moles } \\
\text { to the } \\
\text { mixture }\end{array}$ & $\begin{array}{l}\text { Percentage of } \\
\mathrm{SiO}_{2} \text { in the } \\
\text { raw clay }\end{array}$ & $\begin{array}{l}\text { Percentage } \\
\text { of } \mathrm{SiO}_{2} \text { in } \\
\text { the mixture }\end{array}$ & $\begin{array}{l}\text { Melting } \\
\text { point given } \\
\text { as cone }\end{array}$ & \multicolumn{2}{|c|}{$\begin{array}{c}\text { Softening } \\
\text { temp. chamotte } \\
\text { 4-20 mesh } 7 \text { mesh }\end{array}$} & $\begin{array}{l}\text { Number of } \\
\text { pressure } \\
\text { tests }\end{array}$ \\
\hline 0 & 54.52 & 54.52 & $34-35$ & $8-9$ & 9 & 20 \\
\hline 5 & 54.52 & 57.2 & $33-34$ & $7-8$ & $8-9$ & 24 \\
\hline 15 & 54.52 & 61.6 & $32-33$ & $7-8$ & $8-9$ & 18 \\
\hline 30 & 54.52 & 66.7 & $31-32$ & $6 a-7$ & $7-8$ & 18 \\
\hline 60 & 54.52 & 73.8 & $29-30$ & $8-9$ & $9-10$ & 22 \\
\hline 100 & 54.52 & 79.6 & $28-29$ & IO-11 & $10-I I$ & 24 \\
\hline$\ldots$ & $\ldots$ & 86.8 & $27-28$ & $\cdots$ & $\cdots$ & $\cdots$ \\
\hline$\cdots$ & $\ldots$ & 90.3 & $26-27$ & $\cdots$ & $\cdots$ & . \\
\hline$\cdots$ & $\ldots$ & 93.9 & $29-30$ & $\cdots$ & $\cdots$ & $\ldots$ \\
\hline$\cdots$ & $\cdots$ & 96.4 & 30 & $\cdots$ & $\ldots$ & $\cdots$ \\
\hline
\end{tabular}

The results of the experiments are graphically shown in Fig. 2.

From this sketch it will be seen that a definite minimum for the softening temperature exists between 60 and $70 \%$ silica content. At 60 and $70 \%$ silica content the softening temperature is almost the same and, in both cases, exceeds the temperature for about $67 \%$ silica content by about $25^{\circ} \mathrm{C}$. The minimum for the softening temperature sets in consequently at a considerably lower percentage of silica (between 60 and 70 per cent) than for the cone melting point, for which the minimum lies at about 90 per cent of silica. 
Admixture of $\mathrm{SiO}_{2}$.

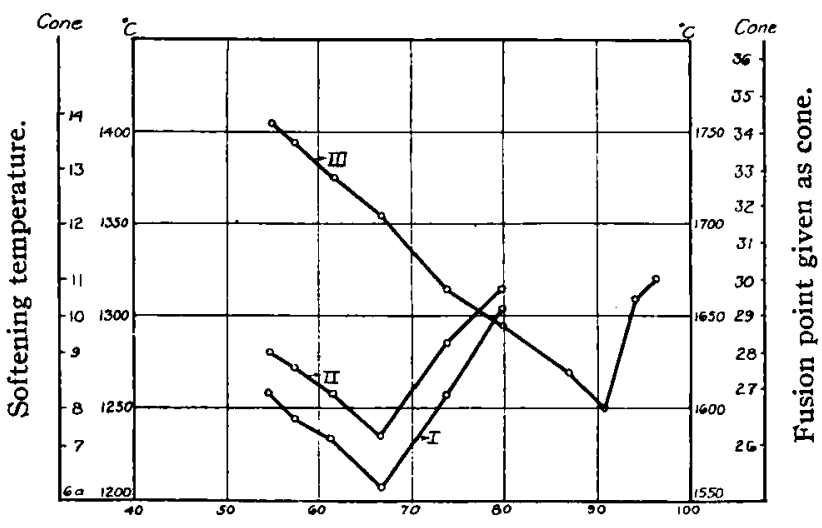

Percentage of $\mathrm{SiO}_{2}$ in the brick.

Fic. 2.-Curve I, Softening temperature chamotte $4-20 \mathrm{~m}$. Curve II, Softening temperature chamotte $7 \mathrm{~m}$.

Curve III, Fusion point given as cone.

Admixture of $\mathrm{Al}_{2} \mathrm{O}_{3}$.

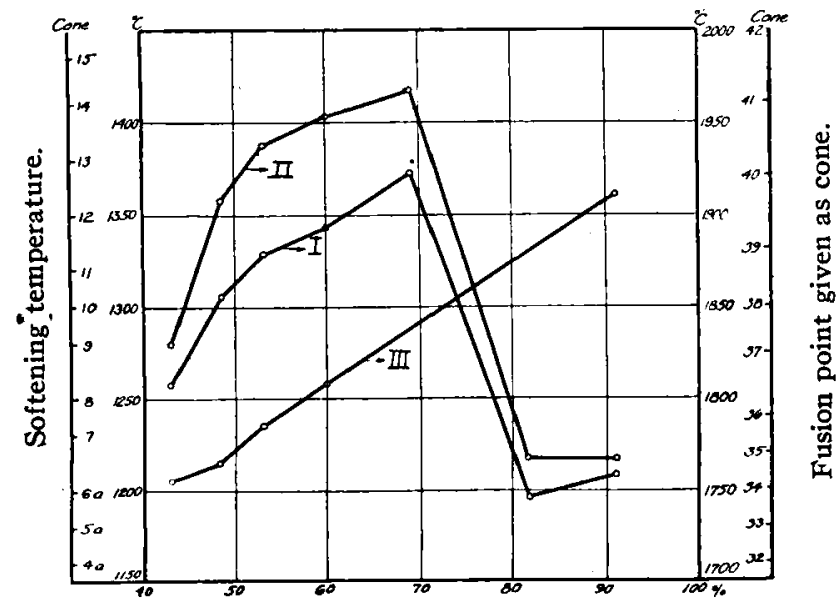

Percentage of $\mathrm{Al}_{2} \mathrm{O}_{3}$ in the brick.

FIg. 3.-Curve I, Softening temperature chamotte $4-20 \mathrm{~m}$. Curve II, Softening temperature chamotte $7 \mathrm{~m}$. Curve III, Fusion point given as cone. 
With a higher percentage of silica, the softening temperature rises rapidly, attaining about $1650^{\circ} \mathrm{C}$ when the percentage of $\mathrm{SiO}_{2}$ reaches about 95 (i.e., the usual average for silica bricks).

From the curves it will be seen that in all cases the coarsegrained mass gives a considerably lower softening temperature than the fine-grained mass, which is certainly due to the presence of certain hollows which cause a more rapid contraction. The fact that the coarse-grained mass shows a lower softening temperature was observed in most of the tests.

\section{Increase of the Percentage of Alumina}

Alumina was added in the form of calcined chemically pure alumina and the results obtained are shown in Table II and Fig. 4.

\begin{tabular}{|c|c|c|c|c|c|c|}
\hline \multirow[b]{2}{*}{$\begin{array}{l}\mathrm{Number} \\
\text { of } \mathrm{AI}_{2} \mathrm{O}_{3} \\
\text { moles } \\
\text { added to } \\
\text { mixture }\end{array}$} & \multirow[b]{2}{*}{$\begin{array}{l}\text { Percentage } \\
\text { of } \mathrm{Al}_{2} \mathrm{O}_{3} \text { in } \\
\text { the raw clay }\end{array}$} & \multirow[b]{2}{*}{$\begin{array}{l}\text { Percentage } \\
\text { of } \mathrm{Al}_{2} \mathrm{O}_{3} \text { in } \\
\text { the mixture }\end{array}$} & \multicolumn{3}{|l|}{ TABLE II } & \multirow[b]{2}{*}{$\underset{\substack{\text { pressure } \\
\text { tests }}}{\text { Number of }}$} \\
\hline & & & $\begin{array}{l}\text { Melting } \\
\text { point given } \\
\text { as cone }\end{array}$ & \multicolumn{2}{|c|}{$\begin{array}{c}\text { Sof tening } \\
\text { temp. chamotte } \\
\text { 4-20 mesh } 7 \text { mesh }\end{array}$} & \\
\hline 0 & 43.04 & 43.0 & $34^{-35}$ & 8-9 & 9 & 20 \\
\hline 5 & 43.04 & 48.4 & $34-35$ & $10-11$ & I2-13 & 20 \\
\hline 10 & 43.04 & 52.9 & $35-36$ & $I I-12$ & $13-14$ & 24 \\
\hline 20 & 43.04 & 59.8 & 36 & $11-12$ & $13-14$ & 22 \\
\hline 40 & 43.04 & 68.9 & 36 & $12-13$ & $14-15$ & 22 \\
\hline 100 & 43.04 & 81.5 & 36 & $5 a-6 a$ & $6 a-7$ & 28 \\
\hline 250 & 43.04 & 90.8 & $39-40$ & $6 a-7$ & $6 a-7$ & 28 \\
\hline
\end{tabular}

With an increased percentage of alumina, the softening temperature rises continuously. The sudden fall noticed with a very high percentage of alumina (about 80 per cent $\mathrm{Al}_{2} \mathrm{O}_{3}$ ) is probably due to the fact that the small quantity of binding clay is not sufficient to keep the alumina grains together. It is not a real softening temperature which is observed here but a sudden collapse owing to the lack of binding material. As in Table $I$, the fine-grained mixture shows a considerably higher softening temperature than the coarse-grained.

\section{Increase of the Percentage of Oxide of Iron}

Chemically pure oxide was added. The result of the investigations are shown in Table III and Fig. 5. 
Admixture of $\mathrm{Fe}_{2} \mathrm{O}_{3}$.

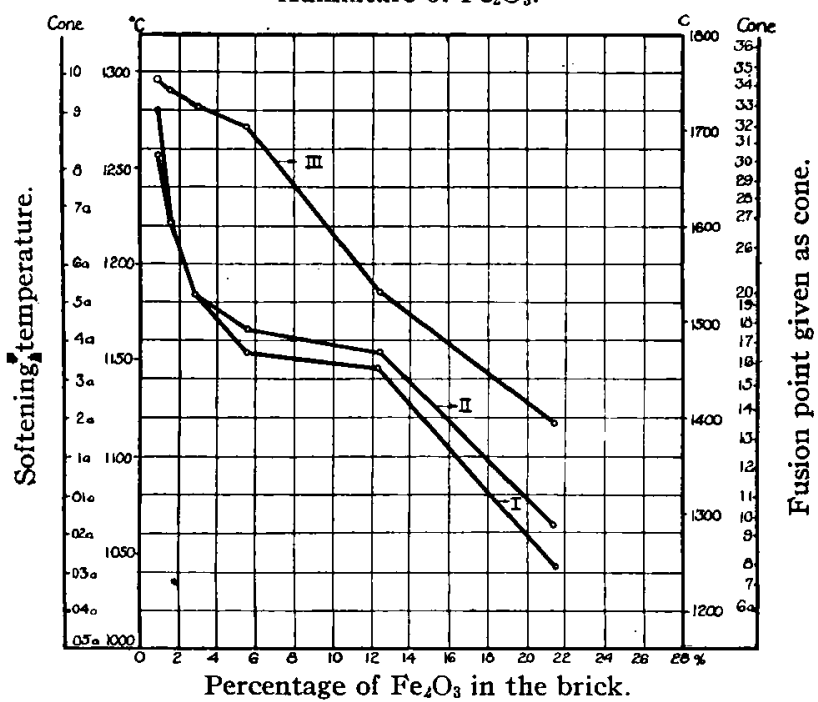

FIG. 4.-Curve I, Sof tening temperature chamotte $4-20 \mathrm{~m}$. Curve II, Softening temperature chamotte $7 \mathrm{~m}$.

Curve III, Frusion point given as cone.

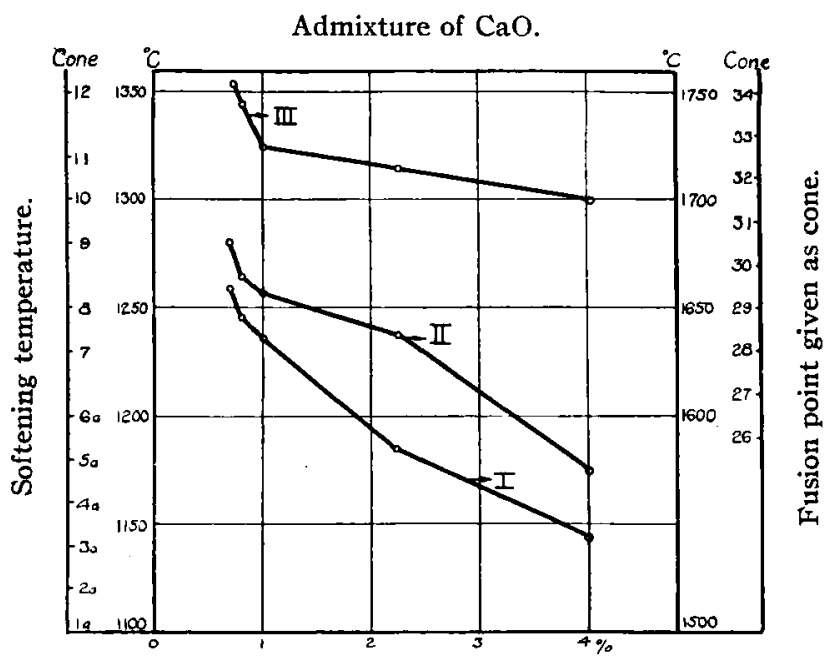

Percentage of $\mathrm{CaO}$ in the brick.

Fig. 5.-Curve I, Softening temperature chamotte 4-20 m.

Curve II, Softening teniperature chamotte $7 \mathrm{~m}$.

Curve III, Fusion point given as cone. 


\begin{tabular}{|c|c|c|c|c|c|c|}
\hline \multirow{2}{*}{$\begin{array}{l}\text { Number } \\
\text { of } \mathrm{Fe}_{2} \mathrm{O}_{3} \\
\text { moles } \\
\text { added to } \\
\text { the mix- } \\
\text { ture }\end{array}$} & \multicolumn{5}{|c|}{ TABLE III } & \multirow[b]{2}{*}{$\begin{array}{c}\text { Number of } \\
\text { pressure } \\
\text { tests }\end{array}$} \\
\hline & $\begin{array}{l}\text { Percentage of } \\
\mathrm{Feg}_{3} \text { in the } \\
\text { raw clay }\end{array}$ & $\begin{array}{c}\text { Percentage } \\
\text { of } \mathrm{Fe}_{2} \mathrm{O}_{3} \\
\text { in the mixture }\end{array}$ & $\begin{array}{l}\text { Melting } \\
\text { point given } \\
\text { as cone }\end{array}$ & \multicolumn{2}{|c|}{$\begin{array}{c}\text { Sof tening } \\
\text { temp. chamotte } \\
\text { 4-20 mesh } 7 \text { mesh }\end{array}$} & \\
\hline 0 & 0.89 & 0.89 & $34^{-35}$ & $8-9$ & 9 & 20 \\
\hline 0.2 & 0.89 & 1.53 & $33-34$ & $6 a-7$ & $6 a-7$ & 22 \\
\hline 0.6 & 0.89 & 2.79 & $32-33$ & $5 a-6 a$ & $5 a-6 a$ & 22 \\
\hline 1.5 & 0.89 & 5.51 & $31-32$ & $3 a-4 a$ & $4 a-5 a$ & 24 \\
\hline 4.0 & 0.89 & 12.32 & 20 near & $3 a-4 a$ & $3 a-4 a$ & 22 \\
\hline 8.0 & 0.89 & 21.40 & $13-14$ & $03 a-02 a$ & $02 a-01 \mathrm{a}$ & 22 \\
\hline
\end{tabular}

An increase of the percentage of iron oxide by 0.64 caused a lowering of the softening temperature of $50^{\circ} \mathrm{C}$. After this point the softening temperature declines more slowly so that it is nearly constant between 6 and 12 per cent $\mathrm{Fe}_{2} \mathrm{O}_{3}$, falling, more rapidly if the percentage of iron oxide is further increased.

Curiously enough, this curve does not show the same difference between coarse and fine grains as do all the other mixtures.

\section{Increase of the Percentage of Lime}

The lime was added as chemically pure precipitated chalk. The results are given in Table IV and Fig. 6.

$\begin{array}{ccccccc}\begin{array}{c}\text { Number } \\ \text { of CaO } \\ \text { moles }\end{array} \\ \begin{array}{c}\text { added to } \\ \text { the mix- } \\ \text { ture }\end{array} & \begin{array}{c}\text { Percentage } \\ \text { the rao in clay }\end{array} & \begin{array}{c}\text { Percentage of } \\ \text { CaO in the } \\ \text { mixture }\end{array} & \begin{array}{c}\text { Melting } \\ \text { point given } \\ \text { as cone }\end{array} & \begin{array}{c}\text { Softening } \\ \text { temp. chamotte } \\ \text { the mesh }\end{array} & \begin{array}{c}\text { Number of } \\ \text { pressure } \\ \text { tests }\end{array} \\ 0 & 0.68 & 0.68 & 34-35 & 8-9 & 0 & 20 \\ 0.1 & 0.68 & 0.79 & 33-34 & 7-8 & 8-9 & 22 \\ 0.3 & 0.68 & 1.02 & 32-33 & 7-8 & 8-9 & 22 \\ 1.4 & 0.68 & 2.25 & 32-33 & 5 a-6 a & 7-8 & 20 \\ 3.0 & 0.68 & 3.98 & 31-32 & 3 a-4 a & 4 a-5 a & 22\end{array}$

The softening temperature is considerably reduced by a slight increase of the lime content. For instance an increase of 0.11 per cent $\mathrm{CaO}$ causes the softening temperature to fall about $25^{\circ} \mathrm{C}$. With a further increase, the softening temperature falls less rapidly, although, of course, the extremely bad influence of this impurity is easily seen from the diagram. 
As the strong influence of so small an increase of lime from 0.68 to 0.79 per cent is distinctly apparent, a material with a still smaller percentage of lime than the raw mixture will certainly show a much higher softening temperature. Investigations are now being made to ascertain the softening temperature with a lime content even lower than 0.68 per cent.

In this case also, the influence of the fineness of the grog may be distinctly observed.

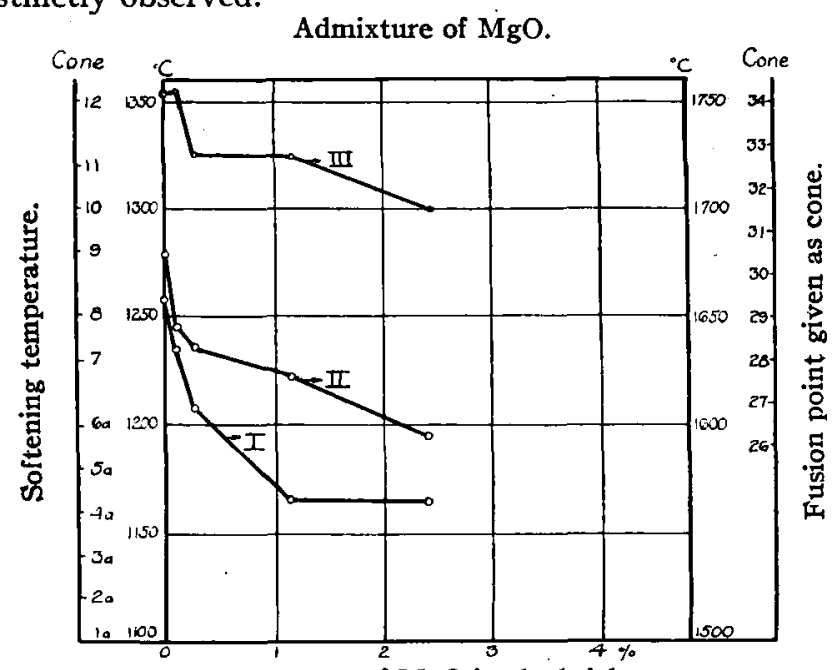

Percentage of $\mathrm{MgO}$ in the brick.

FIG. 6.-Curve I, Softening temperature chamotte 4-20 m.

Curve II, Softening temperature chamotte $7 \mathrm{~m}$.

Curve III, Fusion point given as cone.

\section{Increase of the Percentage of Magnesia}

The results of the investigation are given in Table $\mathrm{V}$ and Fig. 7.

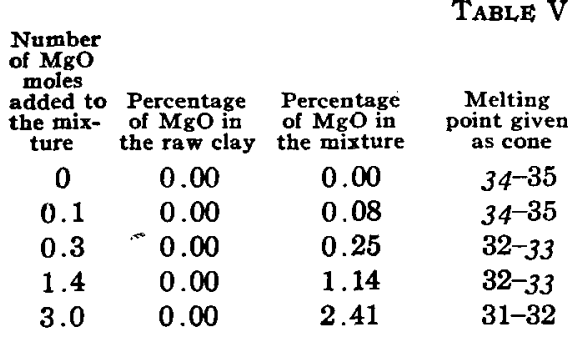

\begin{tabular}{cccc} 
TABLE V & \multicolumn{1}{c}{. } \\
$\begin{array}{c}\text { Melting } \\
\text { point given } \\
\text { as cone }\end{array}$ & $\begin{array}{c}\text { Softening } \\
\text { temp. chamotte } \\
4-20 \text { mesh }\end{array}$ & $\begin{array}{c}\text { Number of } \\
\text { mesh } \\
\text { pressure } \\
\text { tests }\end{array}$ \\
$34-35$ & $8-9$ & 9 & 20 \\
$34-35$ & $7-8$ & $7-8$ & 20 \\
$32-33$ & $6 a-7$ & $7-8$ & 18 \\
$32-33$ & $4 a-5 a$ & $6 a-7$ & 20 \\
$31-32$ & $4 a-5 a$ & $5 a-6 a$ & 20
\end{tabular}


As in the case of lime, a slight increase in the percentage of magnesia has a strong influence in lowering the softening temperature, but to an even greater extent than with lime. Thus an increase of the percentage of $\mathrm{MgO}$ from 0 to $0.08 \%$ causes the softening temperature to fall from $1280^{\circ}$ to $1240^{\circ} \mathrm{C}$.

With 1 per cent of magnesia, the softening temperature is $1220^{\circ} \mathrm{C}$ for the fine-grained mixture, while 1 per cent of $\mathrm{CaO}$ reduces the softening temperature only to $1260^{\circ} \mathrm{C}$.

In this instance also a great difference can be observed between coarse- and fine-grained masses. 